\title{
Communicative Dynamics and the Polyphony of Corporate Social Responsibility in the Network Society
}

\author{
Itziar Castelló • Mette Morsing • Friederike Schultz
}

Published online: 27 November 2013

(C) Springer Science+Business Media Dordrecht 2013

\begin{abstract}
This paper develops a media theoretical extension of the communicative view on corporate social responsibility by elaborating on the characteristics of network societies, arguing that new media increase the speed and connectivity, and lead to higher plurality and the potential polarization of reality constructions. We discuss the implications for corporate social responsibility of becoming more polyphonic and sketch the contours of "communicative legitimacy." Finally, we present this special issue and develop some questions for future research.
\end{abstract}

Keywords Communication · CSR - Legitimacy ·

Network society $\cdot$ Communicative view

\section{Responsible business in network societies}

With the rise of the Internet and social media, and the mediatization of organizations, societies are undergoing a fundamental transformation toward globally networked societies (Castells 2000). Social media such as blogs,

I. Castelló ( $\square)$

Universidad Carlos III de Madrid, C/Madrid 126, 28903 Getafe,

Madrid, Spain

e-mail: macastel@emp.uc3m.es

M. Morsing · F. Schultz

Copenhagen Business School, Porcelaenshaven 18A,

2000 Frederiksberg, Denmark

e-mail:mm.ikl@cbs.dk

F. Schultz

VU University Amsterdam, Amsterdam, The Netherlands

e-mail: fs.ikl@cbs.dk
Facebook, and Twitter have the technological potential to speed up communication (Liu et al. 2006; Gupta et al. 2011) and to increase direct interaction, dialog, and participation across organizations and various audiences (Colleoni 2013; Schultz et al. 2011). Accordingly, social media transform the communicative dynamics within and between corporations and their environment. On the one hand, protest actors can become more powerful and disrupt corporations' legitimacy by using social media (Bennett 2003). On the other hand, corporations can maintain legitimacy better as they can directly relate to their stakeholders via social media and take on the gate keeping function of traditional media (Fieseler et al. 2010).

Overall, research lacks consistent insights into how the institutionalization of social media changes the constitution of corporate legitimacy especially through means of corporate social responsibility (CSR), which has been often regarded as one of the best ways for businesses to address social problems and maintain legitimacy (Gond et al. 2011; Matten and Moon 2008; Moon and Vogel 2008). While theoretical considerations often praise the potential advantages of social media (e.g., Papacharissi 2004), empirical studies point to the more disillusioning implications of new media, for example, the lack of influence of social media protesters in traditional media and public opinion (Kleinnijenhuis et al. in press) or the lack of a dialogical use of social media by corporations (Bortree and Seltzer 2009; Capriotti 2011; Castelló et al. 2013; Fieseler et al. 2010).

So far, CSR research has paid limited attention to social media and its legitimation role of corporations in society, to its characteristics (e.g., Fieseler et al. 2010), its dynamics and relation with traditional media (Lee and Carroll 2011; Siltaouja and Vehkaperä 2010). The predominant instrumental view in CSR research regards CSR 
in an organization-centered manner, primarily as an instrument or a strategic tool (Porter and Kramer 2006, 2011) to foster the business case of CSR by, for example, improving the corporate reputation (e.g., Bhattacharya and Sen 2004), the loyalty and motivation of employees (Turban and Greening 1997) and consumer brand awareness and purchases (Kotler and Lee 2005). As a result, in this view, new media are often seen as fruitful instruments for better stakeholder engagement, for maintaining control and consistent perceptions of their talks and actions, and for building a corporate image that leads to better financial performance. The second dominant view, the politicalnormative view, in turn, regards CSR as a societal, goaldriven consensus making process and sees corporations as being politically responsible for the setting, implementation and development of norms and values of contemporary society (Crane et al. 2008; Etzioni 1988; Ghoshal 2005; Scherer and Palazzo 2007, 2011). This view primarily perceives new media as a vehicle for an increasing participation and dialog that contribute to the formation of consensus by eroding the authority of traditional media, herewith decreasing corporate control over public opinions (Benkler 2006; Chouliaraki and Morsing 2010; Jenkins 2006; Jeppesen and Molin 2003; Tapscott and Williams 2006). Overall, both the instrumental and the politicalnormative view are limited as they focus on hierarchical instead of multiple forms of reality negotiation (controlbias), regard a tight alignment between words and action as crucial for legitimacy building (consistency-bias) and disregard the potential productiveness of dissent and multiple opinions expressed simultaneously (consensus-bias) (Schultz et al. 2013). Furthermore, these views partially build on a technology-deterministic understanding of (new) media, as they extrapolate legitimacy outcomes from technological conditions on social dynamics and do not fully acknowledge the complex forms and new dynamics of interactions between media, publics, and organizations.

This article contributes to this debate by shedding light on the characteristics of social media and how they relate to CSR and the legitimation process of business in society. First, we build on a third view on CSR that has recently emerged, the communicative view (Schultz et al. 2013; see also Golob et al. 2013; Schultz and Wehmeier 2010), which challenges instrumental and political-normative perspectives that propose CSR as instrument for producing consensus, control and consistency. We extend this view with a media theoretical perspective to get a better understanding of the characteristics, dynamics and implications of the interplay between new media and CSR. We explore how new media create a more dynamic context for businesses' legitimacy constitution as they increase the speed of communication and the connectivity of many actors bringing different voices to the debate of corporate responsibilities, what we define as a pluralization process. We point out a number of social conditions that co-determine to what extent different voices finally reach the public's awareness, gain attention from interest groups, foster consensus or dissent, decrease or increase control on corporate messages and disrupt or maintain corporate legitimacy: actors' interpretations, power relations and economic conditions in the interplay with traditional media.

Second, we discuss the implications of these observations for CSR and legitimacy. We argue that the described dynamization of communication can foster and make audible a greater diversity of voices, and partially also more combative voices on business responsibility, whose impact on the constitution of CSR depends not only on their visibility in the debate but also on the capacity of society to acknowledge and recognize them. We conclude that CSR can hardly be reduced to being a corporate function or instrument, but that it needs to be understood as a construct that continuously emerges and changes in the dynamic, media-based interplay between several actors and that it is based on the plurality, conflict and potential polarization of ideas and opinions. Accordingly, we argue CSR needs to become more polyphonic. We draw further conclusions on the concept of legitimacy, arguing that dissent not only disrupts legitimacy (Palazzo and Scherer 2006) but also contributes to dynamically building legitimacy, for example, as it becomes a social expectation in networked societies. We elaborate further on the idea of "communicative legitimacy" as an alternative concept of legitimacy that derives from the dynamics between dissent and consensus.

Finally, we propose a new research agenda to explore the dynamics around corporations and their responsibilities in network societies, and based on that, give a brief outline of the articles in this Special Issue, all of which contribute in one way or another to this research agenda.

\section{Conditions of Corporate Legitimacy: Dynamization of Communication}

As described above, the communicative view challenges instrumental and political-normative views' understanding of communication and media as instruments for producing consensus, control and consistency, and proposes an alternative view on CSR to overcome these biases (Schultz et al. 2013). Central for this view is the idea that communication is not simply a transmission of meaning or interpretations, but a process in which reality is constituted and in which meaning is organized (Putnam and Nicotera 2008; see also Weick 1979, 1995). Communication and 
symbolic representations interactively construct worlds, symbolic forms, narrations and myths about organizations and their legitimacy (Christensen and Cheney 2000, 2011; Meyer and Rowan 1977; Schultz 2011). Organizations are thus also constructs that emerge in (Taylor and Van Every 2000) and consist of communications (Christensen and Cornelissen 2011; Koschmann et al. 2012).

The societal dynamics of individualization, globalization, and fragmentation of reality enhance the importance of the communicative constructions where media play a fundamental role (Chouliaraki and Morsing 2010; Schultz 2011). From a media theoretical point of view, media are technical institutions that transport different systems of signs, e.g., visual, auditive, audio-visual (Saxer 1998). At the same time, they are also social institutions, as they are fundamentally integrated into and constituted by societal and political processes and relations. To understand better the constitution of responsible business and corporate legitimacy in new media environments, it is therefore necessary to develop an integrated view on both the technological characteristics and the societal dynamics around new media.

New Communication Dynamics: Speed, Connectivity, and Plurality

The Internet is considered a technological innovation that has changed communicative processes (DiMaggio et al. 2001), primarily as it increases the speed of transporting information (Castells 2007). This means that information about organizations can be aired and made quickly available via social media platforms such as Facebook and Twitter before being covered by journalist gatekeepers and mass media channels (Castells 2008). The Internet also reduces the technical, financial, and legal barriers of communication, enabling more direct interaction, dialog and participation (Schultz et al. 2011) and herewith more connectivity across geographically dispersed individuals. As communication technologies such as satellites, cable connections and new generations of computers become more available and improve usability, more people can directly access communication platforms, become communicators themselves (Papacharissi 2004) and have their opinions receive more attention. Communication technologies connect diverse social networks and constitute a major modality through which social relationships are created, extended and maintained, thereby leading to a growing alignment of social and communication networks (Friedland et al. 2006). Creating, printing, and distributing a newspaper was an expensive, exclusive, and complex process controlled by only a few people, but many people can set-up a Facebook page, create or participate in blogs
(Castells 2007) and produce other forms of user-generated content (von Hippel 2005) which might democratize the access to communication (Papacharissi 2004).

Not only corporations but also activists and new social movements make intensive use of new media and organize themselves on these infrastructures. They become new media activists (Bennett 2003) or corporate watchdogs, and potentially reach the awareness of millions of people by criticizing corporate behavior; their campaigns, directly and indirectly via classic media (Fieseler et al. 2010), hereby affecting organizations. Also, individuals can participate more easily in debates (Papacharissi 2010) on political issues, especially in countries that lack media transparency or where the traditional media are manipulated by political actors. These new media activists decentralize the discourse without necessarily ascribing to partisan politics or membership in a specific political party, basing their stance on a loose, horizontal and fluid connection via new media (Bennett and Iyengar 2008).

Overall, this increase in speed and connectivity leads to a dynamization of communication, making it more indeterminate as it fosters multi-directional outcomes of communication. A pluralization of voices emerges in societal communication, as more issues are discussed and more opinions are potentially heard. As a result, new media have the technological potential to provide broad access to virtually infinite amounts of information so that online communication has the potential to close informational divides and truly enable deliberative discourse across society. This scenario fits with the idea of a more democratic civil society in which all possible views and arguments can be expressed and in which debate participants can listen, engage in, and exchange non-like-minded views (Scheufele and Nisbet 2012).

As argued, however, the media theoretical view sees media as not only technical institutions but also as social institutions. For that reason, media cannot determine how the interplay between actors finally changes and which of the diverse voices receive more public awareness. It cannot determine the extent to which stakeholder relations can be developed; activists can become more powerful and participation in society can increase, or a reinforcement of selectivity and fragmentation of public discourses along the lines of disagreement can develop, as more pessimistic research reviews argue (Bennett and Iyengar 2008; Donsbach and Mothes 2012). In line with our idea of an integrated perspective, we now take a closer look at the social dynamics upon which the implications of new media depend on the actors' interpretations of these signs, the media used, and the institutional conditions and power relations, such as financial constraints and political pressure. 
Social Dynamics: Actors, Institutions, and Polarization

As communication is an interaction process between two or more actors, the actors' interpretations, expectations and media use co-determine the communicative construction of reality and the consequences of information presented in media. As studies document, new media are, for example, more credible for users with a high level of new media use than for users with little new media affinity (Flanagin and Metzger 2000, 2001; Greer and Moreland 2003; Johnson and Kaye 2004), and the stronger they are related to traditional news sources, the more credible they are perceived (Stavrositu and Sundar 2008). In social media, people also intensively refer to traditional media content, as the latter is often perceived as being neutral. Especially the blogs made by popular journalists of traditional media are regarded as being more credible (e.g., Eisenegger 2008).

As argued above, also the institutional context, the preexistence of political power relations and financial constraints in media organizations, with protesters, political actors, and established journalists from traditional media, co-determine these communicative dynamics in network societies and, finally, extend or limit the described potential of new media toward more connectivity, speed, and diversity. With regard to political conditions we can argue that new media can erode "the authority and agenda-setting power of the traditional media" (Friedland et al. 2006, p. 18) and make the plurality of voices more audible, especially in crises or political conflicts in which, due to a normative consensus or political restrictions on the freedom and plurality of speech (e.g., the Arab Spring and the Iraq War), critical issues cannot be openly discussed in traditional media, but only in the blogosphere (Bennett and Iyengar 2008; Morel 2012). On the other hand, new media partially reproduce the power dimensions of traditional media, where content is organized and presented according to a political line or agenda (Oakes et al. 1998) and according to established organizational hierarchies (Friedland et al. 2006).

Furthermore, both traditional media and new media institutions try to gain more attention, not at least as they operate according to the economic logic of action. Media organizations are also corporations, and reaching a high level of media coverage often leads in both cases to economic advantages in the form of, for example, advertising revenues or donations. To gain the most awareness, media select and communicate issues that, according to news value theory, are locally relevant, sensational, or combative (for traditional media, see Schulz 1976), or ones to which values of good and bad can be attributed (Luhmann 1996). Such issues and bad news, in turn, present a specific idea of reality and are communicated more intensely and broadly in less amount of time, and they also foster the participation of more actors in the communication (see also Hansen et al. 2011). Through scandalous events and moralization (Schultz 2011), and framing them in a specific way building on accepted "schemata of interpretation," as argued in framing theory (Benford and Snow 2000, p. 614; Entman 2007), media reduce communicative complexity, increase awareness of the issues and thus adopt and influence what is discussed in various audiences and how it is evaluated (Carroll and McCombs 2003; McCombs 1997; McCombs et al. 1997; see also agenda-building theory). There is an institutionalization of filtering mechanisms that change the selection and variety of information: Audiences increasingly receive pre-selected information from their social network sites, general search engines and user reviews. Media institutions increasingly use metrics, algorithms as editors, and self-reinforcing search and tagging spirals to decide what information is relevant, especially in times of crises (Scheufele and Nisbet 2012). These filtering mechanisms accordingly change news selection processes and partially reduce the plurality of voices due to economic reasons further.

Social conditions have further implications for communication dynamics in network societies, as they change how people selectively attend to information, comment on issues and negotiate values of good or bad around these issues. When opinions are discussed more in line with likeminded friends or interest groups that actors can easily connect to, new media do not only increase the plurality of voices but can also foster fragmentation of attention and public audiences and increase homogenization within specific communities, as well as disengagement and demobilization, especially for those who lack a strong interest in politics (Donsbach and Mothes 2012). New media can lead to stronger confrontations and selectivity, and herewith polarization in societal debates (Friedland et al. 2006; Nie et al. 2010; Scheufele et al. 2006; Scheufele and Nisbet 2012; Woodly 2008). Simplified frameworks or stereotypes can emerge in extreme positions that become more opposed to each other and defined as being different by moving toward these poles (Pruitt and Olczak 1995). These kinds of oppositional voices and polarization in turn can trigger again diverse debates on corporations, promote participation in these debates and thus also lead to outcomes relevant for society (Scheufele et al. 2006), but it can also strengthen feelings of ambivalence and consequently promote apathy rather than engagement with the political process (Mutz 2002), or even create more conflict.

In view of that, both aspects, plurality and polarization, are two interrelated characteristics of new media societies that also co-determine the debate on responsible businesses and dynamically interact. New media increase the speed of communication and the connectivity of many actors, 
allowing different voices to gain attention, and therefore dynamize communication, but the extent to which it makes debates more plural, or even polarized, depends on actors' interpretations and expectations and on economic and political conditions such as power relations.

\section{The Polyphony of CSR and the Role of Communicative Legitimacy}

As organizations are embedded in multiple, mainly fluid, social and communicative networks, and as new communication technologies catalyze communication processes within organizations and between them and their stakeholders, the described dynamization of communication has fundamental implications for the processes in which business responsibility is constituted. Building on the idea of higher connectivity, speed, pluralization, new media foster and make visible more different and alternative, and often also more combative, voices on business responsibility. Organizations are often confronted with alternative reality constructions about their operations, products, or services. Various audiences and protesters critically observe corporations' actions, evaluate to what extent they are aligned with societal or environmental norms and expectations, and put moral pressure on them, which in turn triggers the institutionalization of CSR (Schultz and Wehmeier 2010). In addition, companies' CSR initiatives and sustainability reports are discussed intensively and critically, and are frequently criticized for being selective (Hess 2008). A higher demand for more transparency on their actions is observable (Christensen 2002) and, hence, a more diverse reality. Often, corporate initiatives are also decoded oppositionally (for oppositional decoding, see Hall 1973) and corporations are accused of greenwashing and being hypocritical, building on the idea that they loosen or decouple their rhetoric from the real societal change (Castelló and Galang 2012; Castelló and Lozano 2011; Göbbels 2002; Schultz and Wehmeier 2010; Brunsson 2003). As the moralization of communication, for which scandalization is one example, increases public awareness concerning issues in the media, polarization of corporate versus protesters' reality constructions might again trigger broader debates on corporations' responsibilities, but also dilute voices in the mass media, leading to a reduction in complexity and thus restrictions on the communication intent.

Chevron's 2010 "We Agree" campaign is an illustration of how social media provide a platform for plurality and conflicting voices. In this case, multiple voices influenced the societal construction of realities by making visible diverse opinions on corporate responsibility in social media tending to a polarization of arguments. In September 2010, Chevron, an American multinational energy corporation, commissioned a sustainability communication campaign called "We Agree" in which a successive number of testimonials presented Chevron CSR achievements. Chevron's corporate managers appeared in the campaign with statements such as, "It's time oil companies get behind the development of renewable energy." They appeared with big posters claiming "We Agree." Environmental activist groups such as Rainforest Action Network and Amazon Watch joined communication specialists and pranksters such as The Yes Men to mimic Chevron's new campaign, derailing it by calling attention to the company's alleged failures and mistakes on a website called "Chevron Thinks We're Stupid," but also on platforms such as blogs, YouTube, Facebook and Twitter, all one day before the original Chevron campaign was launched (Cherry and Sneirson 2012). These media activists contested the corporate message using the same images, modifying them to present an alternate interpretation of Chevron's reality and of the goals that Chevron was supposedly committing to. They claimed, for example: "Oil companies should stop poisoning children. We agree. We believe that as a species human beings define their reality through suffering and misery. We agree." The activists reached thousands of people in California, USA, due to online word-of-mouth and viral effects. The activists' alternate reality construction was given legitimacy and new space on the Internet, and thus competed with the corporate reality construction.

The dynamics of differing opinions and the extent to which they lead to conflict, to a struggle of power in society, and hereby influence the constitution of CSR, depends as argued above on the visibility of the voices in the debate. Conflicting interests and constructions of reality find a technological basis for expression, but receive higher or lower levels of attention and relevance in the public negotiation or reality, depending on the involved actors, institutional conditions and power relations. For example, the plurality of voices emerging via new media also change the overall societal construction of reality through the political influence of traditional news media exercised by the gatekeeping function of professional journalists (Neuberger and Quandt 2010). In the Chevron case, traditional media such as The Washington Post and The Huffington Post provided coverage of the spoof campaign, giving a new level of coverage to the campaign and increasing the impact of the activists.

The impact of new media used by protesters is often counterbalanced by corporate communication efforts, as corporations can also become less dependent on professional journalists, traditional media corporations, and their selection logic. In addition, corporations have the ability to better engage with their multiple stakeholders via new media to create their own spaces for direct dialog with multiple voices. 
E.ON UK, a fully owned subsidiary of the German energy giant E.ON, is another example of how new platforms for hearing multiple voices are being created by corporations. In August 2009, E.ON UK launched "Talking Energy" on YouTube to create a space for open participation that would allow individuals normally excluded from traditional stakeholder dialogs and media coverage to post videos on the UK division's CSR policies and practices. Facilitated and managed by the E.ON UK, this YouTube channel differs from conventional media spaces where journalists filter stakeholder opinions, but also from spaces created by audiences other than the corporation, for example NGOs, to articulate their opinions. In principle, it allowed unaligned individuals and activists from horizontally organized and somewhat amorphous social movement "groups" (e.g., Climate Camp, Climate Rush, Plane Stupid) to post highly critical commentaries on E.ON's CSR policies (e.g., those relating to climate change, energy security and fuel poverty) and break the traditional frontier between formally constituted groups of stakeholders and journalist gatekeepers. At the same time, it established the corporate voice in a space controlled by them (see Whelan, Moon, and Grant in this Special Issue).

\section{Corporate Social Responsibility as Polyphony}

The described dynamization of communication has also further implications for our general understanding and conceptualization of CSR. As argued by Schultz et al. (2013), the communicative view had already begun challenging dominant understandings of CSR as an instrument or management practice that could be defined and managed in a corporate-centric way to produce unity and gain legitimacy. Based on the epistemologically reasoned idea that reality is constituted in communication, CSR can be understood as a communicative construct and dynamic continuum of meaning. CSR comprises not only action but also symbolic aspirations or visions about an ideal future state (Christensen et al. 2013; Schultz et al. 2013; Wehmeier and Schultz 2011), and, in itself, a form of action (Schoeneborn and Trittin 2013; Taylor and Van Every 2000) that shapes these realities communicatively.

Based on our prior thoughts, we can argue that CSR as a construct emerges and changes in the dynamic, mediabased interplay between several actors, and more specifically, in the dynamic interaction between the plurality of voices. Conflicting voices and moral pressure aimed at delegitimizing corporations often enter into the public awareness and trigger debates on the issue of corporation responsibility, which, in turn, fosters the institutionalization of CSR as a concept. These voices challenge corporations' own constructions of, and in particular their idealistic claims on CSR, which have often been introduced as symbolic facades to document a commitment to various stakeholder demands (Schultz and Wehmeier 2010).

We argue, that in the network society, scholars and practitioners would benefit from exploring CSR as a polyphonic concept. The notion of polyphony refers to the idea that several voices are combined into a complex concept in which the individual voices can remain independent identities instead of being integrated into one monophonic voice or instead of being dominated by another homophonic voice (Christensen et al. 2011). Analysis and management of CSR should explore how corporations may integrate the plurality of partially polarized voices and partially incompatible values from their environment at a discursive level. Instead of searching for unity consensus or consistency between talks and actions they have to be able to continuously managing diversity and differences in a flexible way hereby enabling a plurality of voices ambiguity and lack of clarity around CSR. But they also have to integrate diversity by involving stakeholders more directly in the debate to reflect on negotiate and interpret corporate CSR efforts and by giving them a more active role in the institutionalization and constitution of corporations' responsibility and the identity of the organization.

This does not mean that we argue for putting an end to further questions and conflicts about the CSR construct. On the contrary, based on a communication view, it can be argued that the lack of clarity and often ambiguous construction of CSR in new media is a way of serving the interests of the CSR stakeholder community because new media provide "a forum for interaction, sensemaking, dialogue, debate and even conflict among a variety of social actors, groups and interests" (Guthey and Morsing forthcoming).

We argue that the careful orchestration of one consistent and coherent CSR message does not necessarily result in legitimacy across a variety of stakeholders, but might result in a suppression of the many different voices and of the experiences deriving from conflicts losing the tension of the difference (Deetz 1992), or it might even foster them. Dissent, in turn, enriches perceptions and produces tensions that prospectively guide actions (May 2011).

In the communicative perspective of CSR, the role of dissent, plurality of voices and conflict is, for the constitution of CSR, brought forward and becomes central for understanding the legitimation process. As dissent and polarization are fundamental to the dynamics of CSR, we propose to analyze legitimacy as a construct that emerges in interactions during the communicative constitution of CSR and in the interplay of dissent and consensus. Below, we outline the contours of an alternative idea of legitimacy that we summarize under the term communicative legitimacy (see Schultz et al. 2013). 
On the Role of Communicative Legitimacy

Existing conceptualizations on legitimacy argue that an organization is legitimate when it is perceived as being beneficial due to a specific activity that fulfills its own interests (pragmatic legitimacy), or when it does the right thing in a moral sense, which implies that it is beneficial to society (moral legitimacy), or when taken-for-granted beliefs render the organization desirable (cognitive legitimacy; see Suchman 1995). An underlying component is the idea of legitimacy as a state or a quality of being rightful or justifiable that is linked to questions of consent and conformity to societal values (as communicated in the Latin legitimare). As firms are considered legitimate when they conform to such stakeholder expectations (Bansal and Clelland 2004; see also Dowling and Pfeffer 1975; Sen and Bhattacharya 2001; Suchman 1995), especially instrumental views of CSR often tend to frame legitimacy as an objective, instrument or fixed outcome of actions that can be strategically manufactured (Giroux 2006).

This understanding is problematic from a communicative view, as legitimacy is primarily a perception (Suchman 1995) and a relation (Weber 1964) that is developed in interactions by the attempt of one actor to be legitimate and the belief of his counterpart in his legitimacy. Via communication, an actor can become regarded as legitimate and take part in the constitution of reality because he is related to other forms of legitimacy, perceived as being moral or as conforming to cultural beliefs, or as he is, in a more narrow sense, perceived as being "communicable"an accepted member of a discourse, eventually also due to a kind of "communicative rationality" (Habermas 1984).

Based on our insights on the dynamics of communication, we argue that the diversity of voices, conflicting voices and an understanding of potential polarization help to negotiate and herewith share reality. We therefore propose this different understanding of legitimacy that does not regard alignment with specific forms of social acceptance (moral, pragmatic, cognitive) as constitutive, but points to the role of dissent as a necessary condition for the communicative constitution of legitimacy. An organization that is able to appreciate dissent is likely to react to the dissent by diversifying its own reality and become polyphonic, and might be perceived as being legitimate even by those same critical stakeholders and observers who question its behaviors. Dissent can itself become a central norm in network societies and therefore directly constitutive for legitimacy at a meta level. This is what we outline here as communicative legitimacy.

The following section summarizes our findings, draws additional conclusions concerning topics that future research needs to address, and based on that, introduces the articles in this Special Issue.

\section{Agenda for Future Research and Presentation of the Special Issue}

This paper and Special Issue contribute to shedding new light on the communicative dynamics that emerge around CSR and legitimacy in network societies. They partially build on the communicative view on CSR, which provides an alternative to the instrumental and the political-normative views on CSR, their overemphasis on the role of technology and their focus on the notions of control, consensus and consistency (Schultz et al. 2013). We extend this view with a media theoretical perspective, according to which media are not only technological but also social institutions. We argued that new media have the technological capabilities to increase the speed of communication and the connectivity between many actors and different voices, thus increasing the dynamics of communication. This dynamization of communication changes the interplay between business and society, thus leading to a higher plurality and potential polarization of voices, which dynamically interact and can lead to new forms of legitimacy. Their dynamics and influence concerning which voices reach the public consciousness foster consensus or dissent, decrease or increase control on messages, depend on the actors' perceptions of reality and on the institutional conditions, such as power relations, between and within different actors, but also on social and traditional media influences. CSR emerges out of this plurality of voices. Organizations need to understand CSR in its polyphony. Legitimacy emerges within the communicative constitution of CSR, in dissents configured by agentic moments of inclusion, exclusion and break-ups of communication. The idea of communicative legitimacy (see also Schultz et al. 2013) acknowledges that legitimacy emerges in a dynamic, often dissensual, instead of consensual process of communication.

Corporations already started to react to these changes in network societies. Even though corporate activities are still mainly communicated in a traditional unidirectional manner via corporate press releases and corporate reports (see early models of PR according to Grunig and Hunt 1984), they increasingly acknowledge social media channels as fruitful platforms for observing public opinion and managing critical issues, and as a channel for communicating or engaging with multiple stakeholders. As argued by Castelló et al. (2013), some corporations are starting to think about the importance of transforming firm-centric and controlled communication strategies to a more open and multi-directional form of communication, which should allow them to communicate broadly and to participate in debates from which they were previously excluded. Corporations need to use social media to reflect on how to go beyond their traditional definition of stakeholders as 
"functional groups" (e.g., consumers, employees, shareholders, suppliers, NGOs) who might impact corporate activities through their agitation in a risky way to seeing them as potential innovative collaborators on environmental issues concerning the company as well as concerning society (see Whelan 2012; Den Hond and De Bakker 2007). Instead of maintaining legitimacy in traditional corporate-centric ways (Lozano 2005) via stakeholder management or CSR departments or other meta-platforms of coordination, corporations need to acknowledge the polyphony of social media and work in other forms of participating in the legitimation process. Flexible networks of engagement and terms of engagement that facilitate exchanges between multiple and individual activists and the corporations without neglecting institutional stakeholders (Castelló et al. 2013) have been suggested as forms of acknowledging plurality of voices and dissent. The creation of these structures requires understanding corporate relations with its publics through communicative lenses that make visible the co-construction of networks of engagements, influence and power relations between the different actors participating in new media platforms and the opportunity for companies to work under conditions of "uncontrol" (Castelló et al. 2013).

\section{Future Research Perspectives}

Further research needs to extend these contours outlining the characteristics of CSR in networked societies and broaden our understanding of how communicative legitimacy is constituted. This Special Issue on "Responsible Business in Social Media: Toward New Forms of Interaction?" opens up the debate to three lines of future research and presents articles that contribute to further developing our understanding of business and society relations.

First, research needs to shed more light on the communicative dynamics of CSR and discuss how the general technological conditions of new media, but also the role of actors vis á vis social and political influence, change communication dynamics, and the constitution of legitimacy. In particular, the concrete interplay between social media and traditional news media can help to further understand how much influence traditional centralized actors have in the definition of agendas. How is CSR constituted in polyphonic and uncontrolled debates and what are the dynamic interactions between this polyphony and polarization? How do actors' perceptions and institutional conditions constitute awareness in these debates and what, then, is the impact of protesters who articulate their critical opinions via social media on the public and corporations, and the impact of traditional actors using traditional media? And how does the interplay between them lead to societal conflicts about corporations and social issues, and what are the dysfunctional effects of CSR on corporate legitimacy? A number of papers in this Special Issue contribute to shedding more light on these issues.

The polyphonic character of CSR is expanded and further analyzed in Meg-Lee, van Dolen, and Kolk's "The Role of Social Media in 'Responsible' Food ...," which examines blogger buzzes in reaction to food companies' press releases on health and obesity issues. The authors suggest that companies can increase the likelihood of a positive reaction if they carefully consider the fit between initiatives and their core business, while taking the notion of controversial fit relating to the unhealthy nature of original products into account. Meg-Lee et al. document that bloggers' responses are influenced not only by the bloggers' individual beliefs about responsibility but also by different informational cues in press releases. They highlight the complexity of managing the polyphonic voices of CSR and suggest that future research on the polyphonic character of CSR should study blogger responses toward a company's proactive social media strategy in different circumstances and points in time.

The polyphony of CSR is also considered in Besiou, Hunter, and Van Wassenhove's "A Web of Watchdogs ...," which discusses three cases on protests against multinational corporations. Their theoretical objective is to develop agenda-setting theory toward a more dynamic and nonlinear networked stakeholder context in which stakeholder-controlled media take over parts of the roles that have previously been ascribed to mainstream media. They present a model of stakeholder responses to the agendas of management and other stakeholders. They build on a system-dynamic model and argue that robust system-dynamic models may enable not only a clearer dissection of the paths of stakeholder feedback but also may foresee and resolve the underlying issues behind that path.

Eberle, Berens, and Li's on "The Impact of Interactive CSR Communication on Corporate Reputation" contribute to a better understanding of communicative dynamics of CSR in terms of the impacts of interactivity in CSR messages communicated via social media on corporate reputation and recipients' word-of-mouth intentions. They suggest that an increase in perceived interactivity leads to higher message credibility and stronger feelings of identification with the company, which also boost corporate reputation and word-of-mouth in a positive way. They also argue, however, that the detrimental impacts of negative user evaluations on corporate reputation are much higher than the favorable impacts of positive evaluations. Interactivity and word-of-mouth are good examples of the multiple interactions of corporations with different actors and the importance of understanding the dynamics of communication. 
Lyon and Montgomery's "Tweetjacked: The Impact of Social Media on Corporate Greenwash" contribute to developing a better understanding of how corporate CSR messages become oppositionally decoded and how debates become polarized. Lyon and Montgomery present a theoretical framework for understanding greenwashing, where corporate environmental communications may backfire if citizens and activists feel a company is engaging in excessive self-promotion. They identify important differences between social media and traditional media and draw on management literature on decoupling and economic literature on information disclosure to theorize how social media reduce the incidence of corporate greenwashing.

In their article "The Pursuit of Empowerment through Social Media," Fieseler and Fleck delve deeper into the conflicts that emerge through social media. They utilize social network analysis to investigate the CSR blogs of three IT firms: Google, Hewlett-Packard, and Intel. Their analysis reveals that the Internet-enabled social networks of these companies exhibit patterns of power-law distribution and an uneven distribution of structural social capital among the actors involved, especially on the corporate side, which fails to fully engage with the network. They argue that companies can no longer shield themselves from the involvement of stakeholders. In contrast to large mass media audiences, social media attracts fewer people and especially those who actively look for conversation and want to engage in online discussions. They conclude that social media might not have a direct impact on the larger public sphere, but can indirectly reach the larger public through opinion leaders.

In their article "Corporations and Citizenship Arenas in the Age of Social Media," Whelan, Moon, and Grant argue that corporate communication via social media is mainly populated by individual citizens instead of functionallyformally organized stakeholders. Individual citizens are empowered, relative to corporations and their functionallyformally organized stakeholders, when it comes to creating, debating, and publishing CSR relevant issues. However, information and communication technology corporations possess specific, and potentially very important capacities, when it comes to creating or helping to construct public arenas of citizenship from within which individual citizens can influence their broader politicaleconomic environment. They conclude that the role of conflict and power relations needs to be further investigated in future research. We agree with this insight. Further research on communicative connectedness needs to develop more insights on polarization and stakeholder conflicts in polyphonic debates, as well as develop a better understanding of the role of dissent for corporate legitimacy.
Finally, Lee, Oh, and Kim's article, "Social Media for Socially Responsible Firms ...," also deals with the conflictual character of CSR by examining the issue of how to better exercise control over communications. Using a large database of companies, they study the influence and control of corporations over the stakeholder agenda of CSR. They argue that while social media create important momentum for firms to cultivate favorable stakeholder relationships, the opportunities this affords are not distributed evenly for all firms. They investigate the impact of CSR credentials on the effectiveness of social media as a stakeholder-relationship management platform. They maintain that socially responsible firms can harvest proactive stakeholder participation (user-driven communication) without investing more resources (firm-driven communication) and conclude that being socially responsible makes more practical sense for firms with the rise of social media.

We identify the second line of future research as one that needs to investigate more how to apply and combine new methods to observe these changes on a broader scale. To analyze the dynamic interplay between actors (opinions, views), their personal relations and the emergence of new forms of relations between organizations and activist, semantic network analyses (Monge and Contractor 2001) and social network analysis and their combinations might be fruitful. De Bakker and Hellsten's article, "Capturing Online Presence: Hyperlinks and Semantic Networks in Activist Group Websites on CSR," contributes to this aim as it proposes and tests these new methods for studying communication dynamics. They present an explorative study of activist groups' online presence via their websites and propose a combination of methods to study both the structural positioning of websites (hyperlink network analysis) and the meanings in these websites (semantic coword maps). This method can improve our understanding of the tactics of activist networks to achieve institutional change on CSR issues. The combination of methods and the exploration of big data might provide further insights into how social media influence and are influenced by actors, mediums and institutions.

Finally, we propose that the third line of future research should aim at developing further conceptualization and analysis of the role of communicative legitimacy that goes beyond cognitive, instrumental, and moral legitimacy perspectives and that contributes to understanding communicative complexities. Legitimacy is constituted in communication, but both sides of communication-the "loved" side of consensus, control and consistency as well as the "unloved" side of conflict or dissent, uncontrol and inconsistency-are fundamental for the constitution of legitimacy. Conflict and dissent, in turn, derive out of the polyphony and polarization we described. How legitimacy 
constitution changes in network societies depends, as described, on actors, institutional conditions, and media dynamics. Research needs to better analyze how legitimacy is communicatively constituted in these dynamic interactions under a plurality of voices and narrations represented in new and traditional media, and how this polyphony and dissent become integral part of the legitimization process. Such exploration of legitimacy can help us to grasp the conditions and processes, under which actors are able to participate in discourses and interact in the new communication space in order to negotiate reality. We need to understand better how it can foster not only the unique capacity to engage multiple voices and embrace dissent in a way that other concepts may not but also serves as a catalyst for important discussions about the ability of companies to engage with stakeholders.

Our proposal to build on communicative and media theory to better understand the complex process of corporate legitimization and responsible business in the network society is only a first step. We would like to invite you to join our debate, and explore the communicative view on CSR.

Acknowledgments All three authors want to thank the Strategic Research Council under the Danish Ministry of Science, Technology and Innovation for generous support to the "Responsible Business in the Blogosphere," which is the framework of this research project. We also thank the CIEL Entrepreneurship Research Accelerator for financing The 2nd Annual Social Media for Social Purposes Conference at Copenhagen that lead to this Special Issue.

\section{References}

Bansal, P., \& Clelland, I. (2004). Talking trash: Legitimacy, impression management, and unsystematic risk in the context of the natural environment. Academy of Management Journal, 47(1), 93-103.

Benford, R. D., \& Snow, D. A. (2000). Framing processes and social movements: An overview and assessment. Annual Review of Sociology, 26, 611-639.

Benkler, Y. (2006). The wealth of networks: How social production transforms markets and freedom. New Haven, CT: Yale University Press.

Bennett, W. L. (2003). New media power: The Internet and global activism. Oxford: Rowman and Littlefield.

Bennet, W. L., \& Iyengar, S. (2008). A new era of minimal effects? The changing foundations of political communication. Journal of Communication, 58(1), 707-731.

Bhattacharya, C. B., \& Sen, S. (2004). Doing better at doing good: When, why and how consumers respond to corporate social initiatives. California Management Review, 47(1), 9-24.

Bortree, D. S., \& Seltzer, T. (2009). Dialogic strategies and outcomes: An analysis of environmental advocacy groups' Facebook profiles. Public Relations Review, 35(3), 317-319.

Brunsson, N. (2003). Organised hypocrisy. In B. Charniawska \& G. Sevon (Eds.), The Northern lights: Organisation theory in Scandinavia. Copenhagen: Copenhagen Business School Press.

Capriotti, P. (2011). Communicating corporate social responsibility through the Internet and social media. In $\varnothing$. Ihlen, J. L. Bartlett,
\& S. May (Eds.), The handbook of communication and corporate social responsibility. Hobokon, $\mathrm{NJ}$ : Wiley.

Carroll, C. E., \& McCombs, M. E. (2003). Agenda-setting effects of business news on the public's images and opinions about major corporations. Corporate Reputation Review, 6(1), 36-46.

Cherry, M. A., \& Sneirson, J. F. (2012). Chevron, Greenwashing, and the Myth of 'Green Oil Companies'. Journal of Energy, Climate, and the Environment, 3(1). http://scholarlycommons.law.wlu. edu/jece/vol3/iss $1 / 5$.

Castelló, I., Etter, M., \& Nielsen, F. A. (2013). Legitimacy building in the networked society and the locus of control. Journal of Management Studies, Manuscript Development Workshop on "Managing for Political Corporate Social Responsibility". Copenhagen, Denmark.

Castelló, I., \& Galang, R. (2012). Looking for new forms of legitimacy in Asia. Business and Society, published online 21 December 2012. doi:10.1177/0007650312469864.

Castelló, I., \& Lozano, J. M. (2011). Searching for new forms of legitimacy through corporate responsibility rhetoric. Journal of Business Ethics, 100(1), 11-29.

Castells, M. (2000). The rise of the network society. Oxford: Blackwell.

Castells, M. (2007). Communication, power and counter-power in the network society. International Journal of Communication, 1, 238-266.

Castells, M. (2008). The new public sphere: Global civil society, communication networks, and global governance. The Annals of the American Academy of Political and Social Science, 616(1), 78-93.

Chouliaraki, L., \& Morsing, M. (2010). Media, organizations, and identity. London: Palgrave MacMillan.

Christensen, L. T. (2002). Corporate communication: The challenge of transparency. Corporate Communications: An International Journal, 7(3), 162-168.

Christensen, L. T., \& Cheney, G. (2000). Self-absorption and selfseduction in the corporate identity game. In M. Schultz, M. J. Hatch, \& M. H. Larsen (Eds.), The expressive organization: Linking identity, reputation and the corporate brand (pp. 246-270). Oxford: Oxford University Press.

Christensen, L. T., \& Cheney, G. (2011). Interrogating the communicative dimensions of corporate social responsibility. In $\varnothing$. Ihlen, J. Bartlett, \& S. May (Eds.), Handbook of communication and corporate social responsibility (pp. 491-504). Malden, MA: Wiley.

Christensen, L. T., \& Cornelissen, J. (2011). Bridging corporate and organizational communication: Review, development and a look to the future. Management Communication Quarterly, 25(3), 383-414.

Christensen, L. T., Morsing, M., \& Thyssen, O. (2011). The polyphony of corporate social responsibility: Deconstructing accountability and transparency in the context of identity and hypocrisy. In G. Cheney, S. May, \& D. Munshi (Eds.), Handbook of communication ethics (pp. 457-474). New York: Routledge.

Christensen, L. T., Morsing, M., \& Thyssen, O. (2013). CSR as aspirational talk. Organization, 20(3), 372-393.

Colleoni, E. (2013). CSR communication strategies for organizational legitimacy in social media. Corporate Communications: An international Journal, 18(2), 228-248.

Crane, A., Matten, D., \& Moon, J. (2008). Corporations and citizenship. Cambridge: Cambridge University Press.

Deetz, S. (1992). Democracy in an age of corporate colonization: Developments in communication and the politics of everyday life. Albany, NY: State University of New York Press.

Den Hond, F., \& De Bakker, F. G. A. (2007). Ideologically motivated activism: How activist groups influence corporate social change activities. Academy of Management Review, 32(3), 901-924. 
DiMaggio, P., Hargittai, E., Neuman, W. R., \& Robinson, J. P. (2001). Social implications of the Internet. Annual Review of Sociology, 27, 307-336.

Donsbach, W., \& Mothes, C. (2012). The dissonant self: Contributions from dissonance theory to a new agenda for studying political communication. In C. T. Salmon (Ed.), Communication Yearbook 36 (pp. 3-44). New York, NY: Routledge.

Dowling, J., \& Pfeffer, J. (1975). Organizational legitimacy: Social values and organizational behavior. Pacific Sociological Review, $18(1), 122-136$.

Eisenegger, M. (2008). Blogomanie und Blogophobie: Organisationskommunikation im Sog technizistischer Argumentationen. In C. Thimm \& S. Wehmeier (Eds.), Organisationskommunikation online: Grundlagen (pp. 32-54). Praxis, Empirie: Frankfurt am Main.

Entman, R. M. (2007). Framing bias: Media in the distribution of power. Journal of Communication, 57(1), 163-173.

Etzioni, A. (1988). The moral dimension: Towards a new economics. New York: The Free Press.

Fieseler, C., Fleck, M., \& Meckel, M. (2010). Corporate social responsibility in the blogosphere. Journal of Business Ethics, 91, 599-614.

Flanagin, A. J., \& Metzger, M. M. (2000). Perceptions of internet information credibility. Journalism and Mass Communication Quarterly, 77(3), 515-540.

Flanagin, A. J., \& Metzger, M. J. (2001). Internet use in the contemporary media environment. Human Communication Research, 27(1), 153-181.

Friedland, L. A., Hove, T., \& Rojas, H. (2006). The networked public sphere. Javnost: The Public, 13(4), 5-26.

Ghoshal, S. (2005). Bad management theories are destroying good management practices. Academy of Management Learning and Education, 4(1), 75-91.

Giroux, H. (2006). It was such a handy term: Management fashions and pragmatic ambiguity. Journal of Management Studies, 43(6), 1227-1260.

Göbbels, M. (2002). Reframing corporate social responsibility: The contemporary conception of a fuzzy notion. Rotterdam: Erasmus University Rotterdam.

Golob, U., Elving, W., Nielsen, A.-E., Podnar, K., Schultz, F., \& Thomson, C. (Eds.). (2013). CSR and communication: The communication of the ethical position of an organization. Special Issue in Corporate Communications: An International Journal.

Gond, J. P., Kang, J., \& Moon, J. (2011). The government of selfregulation: On the comparative dynamics of corporate social responsibility. Economy and Society, 40(4), 640-671.

Greer, C. F., \& Moreland, K. D. (2003). United Airlines' and American Airlines' online crisis communication following the September 11 terrorist attacks. Public Relations Review, 29(4), 427-441.

Grunig, J. E., \& Hunt, T. T. (1984). Managing public relations. New York: Harcourt Brace Jovanovich College Publishers.

Gupta, S., Armstrong, K., \& Clayton, Z. (2011). Social media. Boston, MA: Harvard Business School Publishing.

Guthey, E.. \& Morsing, M. (forthcoming). CSR as an act of strategic ambiguity: A Longitudinal analysis of CSR in the media. Journal of Business Ethics.

Habermas, J. (1984). The theory of communicative action. Reasons and the rationalization of society (Vol. 1). Boston, MA: Bacon Press.

Hall, S. (1973). Encoding and decoding in the television discourse. Centre for Cultural Studies, University of Birmingham, CCS Stenciled Paper no. 7.

Hansen, L. K., Arvidsson, A., Nielsen, F. A., Colleoni, E., \& Etter, M. (2011). Good friends, bad news: Affect and virality in Twitter.
Future Information Technology Communications in Computer and Information Science, 185, 34-43.

Hess, D. (2008). The three pillars of corporate social reporting as new governance regulation: Disclosure, dialogue, and development. Business Ethics Quarterly, 18, 447-482.

Jenkins, H. (2006). Convergence culture: Where old and new Media Collide. New York: New York University Press.

Jeppesen, L. B., \& Molin, M. J. (2003). Consumers as co-developers: Learning and innovation outside the firm. Technology Analysis and Strategic Management, 15(3), 363-384.

Johnson, T. J., \& Kaye, B. K. (2004). Wag the blog: How reliance on traditional media and the internet influence perceptions of credibility of weblogs among blog users. Journalism and Mass Communication Quarterly, 81(3), 622-642.

Kleinnijenhuis, J., Utz, S., Schultz, F., \& Oegema, D. (in press). The mediating role of US News in the BP oil spill: How the news depends on BP and how it affects public awareness, UK news and the BP share price. Communication Research.

Koschmann, M. A., Kuhn, T. R., \& Pfarrer, M. D. (2012). A communicative framework of value in cross-sector partnerships. Academy of Management Review, 37(3), 332-354.

Kotler, P., \& Lee, N. (2005). Corporate social responsibility: Doing the most good for your company and your cause. Hobokon, NJ: Wiley.

Lee, S. Y., \& Carroll, C. E. (2011). The emergence, variation, and evolution of corporate social responsibility in the public sphere, 1980-2004: The exposure of firms to public debate. Journal of Business Ethics, 104(1), 115-131.

Liu, H., Maes, P., \& Davenport, G. (2006). Unraveling the taste fabric of social networks. International Journal on Semantic Web and Information Systems, 2(1), 42-71.

Lozano, J. M. (2005). Towards the relational corporation: From managing stakeholder relationship to building stakeholder relationships (waiting for Copernicus). Corporate Governance, 5(2), 60-77.

Luhmann, N. (1996). Die Realität der Massenmedien (2nd ed.). Opladen: Westdeutscher Verlag.

Matten, D., \& Moon, J. (2008). Implicit and explicit CSR: A conceptual framework for a comparative understanding of corporate social responsibility'. Academy of Management Review, 33(2), 404-424.

May, S. (2011). Organizational communication and corporate social responsibility. In Ø. Ihlen, J. L. Bartlett, \& S. May (Eds.), The handbook of communication and corporate social responsibility (pp. 87-109). Oxford: Wiley.

McCombs, M. (1997). Building consensus: The news media's agenda-setting roles. Political Communication, 14(4), 433-443.

McCombs, M., Shaw, D. L., \& Weaver, D. (1997). Communication and democracy: Exploring the intellectual frontiers in agendasetting theory. Mahwah, NJ: Lawrence Erlbaum Associates Inc.

Meyer, J., \& Rowan, B. (1977). Institutionalized organizations: Formal structure as myth and ceremony. American Journal of Sociology, 83, 340-363.

Monge, P. R., \& Contractor, N. S. (2001). Emergence of communication networks. In F. M. Jatblin \& L. L. Utnam (Eds.), The New Handbook of Organizational Communication: Advances in Theory, Research, and Methods (pp. 440-502). Sage Publications, Inc.

Moon, J., \& Vogel, D. (2008). Corporate social responsibility, government, and civil society. In A. Crane, A. McWilliams, D. Matten, J. Moon, \& D. Siegel (Eds.), The Oxford handbook of corporate social responsibility. Oxford: Oxford University Press.

Morel, M. F. (2012). The free culture and 15 M movements in Spain: Composition, social networks and synergies. Social Movement Studies, 11(3-4), 86-392.

Mutz, D. C. (2002). The consequences of cross-cutting networks for political participation. American Journal of Political Science, 46(4), 838-855. 
Neuberger, C., \& Quandt, T. (2010). Internet-Journalismus: Vom traditionellen Gatekeeping zum partizipativen Journalismus? In W. Schweiger \& K. Beck (Eds.), Handbuch Online-Kommunikation (pp. 59-79). Wiesbaden: VS-Verlag.

Nie, N. H., Miller, D. W., Golde, S., Butler, D. M., \& Winneg, K. (2010). The world wide web and the U.S. political news market. American Journal of Political Science, 54(2), 428-439.

Oakes, L., Townley, B., \& Cooper, D. (1998). Business planning as pedagogy: Language and control in a changing institutional field. Administrative Science Quarterly, 43(2), 257-292. (reprinted 2005, 2008 in G. Johnson, A. Langley, L. Melin, R. Whittington Strategy as Practice. Cambridge: Cambridge University Press, pp. 152-164).

Palazzo, G., \& Scherer, A. (2006). Corporative legitimacy as deliberation: A communicative framework. Journal of Business Ethics, 66(1), 71-88.

Papacharissi, Z. (2004). Democracy online: Civility, politeness, and the democratic potential of online political discussion groups. New Media and Society, 6(2), 259-284.

Papacharissi, Z. (2010). A Private Sphere, Democracy in a Digital Age. Malden, MA: Polity Press.

Porter, M. E., \& Kramer, M. (2006). Strategy and society: The link between competitive advantage and corporate social responsibility. Harvard Business Review, 84(12), 78-93.

Porter, M., \& Kramer, M. (2011). Creating shared value. Harvard Business Review, 89(1/2), 62-77.

Pruitt, D., \& Olczak, P. (1995). Beyond hope: Approaches to resolving seemingly intractable conflict. In B. Bunker, J. Rubin, et al. (Eds.), Conflict, cooperation, and justice: Essays inspired by the work of Morton Deutsch (pp. 59-92). San Francisco: Jossey-Bass Publishers Inc.

Putnam, L. L., \& Nicotera, A. M. (2008). Building theories of organization: The constitutive role of communication. Oxford: Routledge.

Saxer, U. (1998). Mediengesellschaft: Verständnisse und Mißverständnisse. In U. Sarcinelli (Ed.), Politikvermittlung und Demokratie in der Mediengesellschaft. Opladen: Westdeutscher Verlag.

Scherer, A., \& Palazzo, G. (2007). Toward a political conception of corporate responsibility: Business and society seen from a Habermasian perspective. Academy of Management Review, 32(4), 1096-1120.

Scherer, A. G., \& Palazzo, G. (2011). The new political role of business in a globalized world: A review of a new perspective on CSR and its implications for the firm, governance, and democracy. Journal of Management Studies, 48(4), 31-889.

Scheufele, D. A., Hardy, B. W., Brossard, D., Waismel-Manor, I. S., $\&$ Nisbet, E. (2006). Democracy based on difference: Examining the links between structural heterogeneity, heterogeneity of discussion networks, and democratic citizenship. Journal of Communication, 56(4), 728-753.

Scheufele, D. A., \& Nisbet, M. C. (2012). Online news and the demise of political disagreement. In C. T. Salmon (Ed.), Communication Yearbook 36. New York: Routledge.

Schoeneborn, D., \& Trittin, H. (2013). Transcending transmission: Towards a constitutive perspective on CSR communication. Corporate Communications: An International Journal, 18(2), 193-211.
Schultz, F., Castelló, I., \& Morsing, M. (2013). The communicative construction of CSR: A mediation perspective. Journal of Business Ethics, 15(4), 681-692.

Schultz, F., Utz, S., \& Göritz, A. (2011). Is the medium the message? Perceptions of and reactions to crisis communication via Twitter, blogs and traditional media. Public Relations Review, 37(1), 20-27.

Schultz, F., \& Wehmeier, S. (2010). Institutionalization of corporate social responsibility within corporate communications. Combining institutional, sensemaking and communication perspectives. Corporate Communications: An International Journal, 15(1), 9-29.

Schulz, W. (1976). Die Konstruktion von Realität in den Nachrichtenmedien. Freiburg/München: Alber.

Schultz, F. (2011). Moral-Kommunikation-Organisation. Funktionen und Implikationen normativer Konzepte und Theorien des 20. Und 21. Jahrhunderts. Wiesbaden, Germany: VS-Verlag.

Sen, S., \& Bhattacharya, C. B. (2001). Does doing good always lead to doing better? Consumer reactions to corporate social responsibility. Journal of Marketing Research, XXXVIII, 225-243.

Siltaouja, M. E., \& Vehkaperä, M. J. (2010). Constructing illegitimacy? Cartels and cartels agreements in Finnish business media from critical discourse perspective. Journal of Business Ethics, 92(4), 493-511.

Stavrositu, C., \& Sundar, S. S. (2008). If internet credibility is so iffy, why the heavy use? The relationship between medium use and credibility, Cyberpsychology, 11(1), 65-68.

Suchman, M. (1995). Managing legitimacy: Strategic and institutional approaches. Academy of Management Review, 20(3), 571-610.

Tapscott, D., \& Williams, A. (2006). Wikinomics: How mass collaboration changes everything. New York: Portfolio.

Taylor, J. R., \& Van Every, E. J. (2000). The emergent organization: Communication as its site and surface. Mahwah, NJ: Erlbaum.

Turban, D. B., \& Greening, D. W. (1997). Corporate social performance and organizational attractiveness to prospective employees. Academy of Management Journal, 40(3), 658-672.

Von Hippel, E. (2005). Democratizing innovation. Cambridge, MA: MIT Press.

Weber, M. (1964). Wirtschaft und Gesellschaft. Grundriß der verstehenden Soziologie. Studienausgabe (Vol. 1). Berlin: Kiepenheuer and Witsch.

Wehmeier, S., \& Schultz, F. (2011). Corporate communication and corporate social responsibility: A storytelling perspective. In O. Ihlen, J. Bartlett, \& S. May (Eds.), Handbook of communication and corporate social responsibility. Wiley-Blackwell: Boston, MA.

Weick, K. (1979). The social psychology of organizing. Reading: Addison-Wesley.

Weick, K. (1995). Sensemaking in organizations. Thousand Oaks, CA: SAGE Publications.

Whelan, G. (2012). The political perspective of corporate social responsibility: A critical research agenda. Business Ethics Quarterly, 22(4), 709-737.

Woodly, D. (2008). New competencies in democratic communication? Blogs, agenda setting and political participation. Public Choice, 134, 109-123. 